\title{
A simple method of catalase purification for the undergraduate experimental course
}

\author{
QIAN CHEN $^{1 *}$, MENG CHENG $^{2 *}$, YINNAN WANG $^{2}$, MING YAO $^{3}$, \\ YONGCHUN CHEN $^{3}$, YUAN GAO ${ }^{3}$ and WENYUAN DING ${ }^{1}$

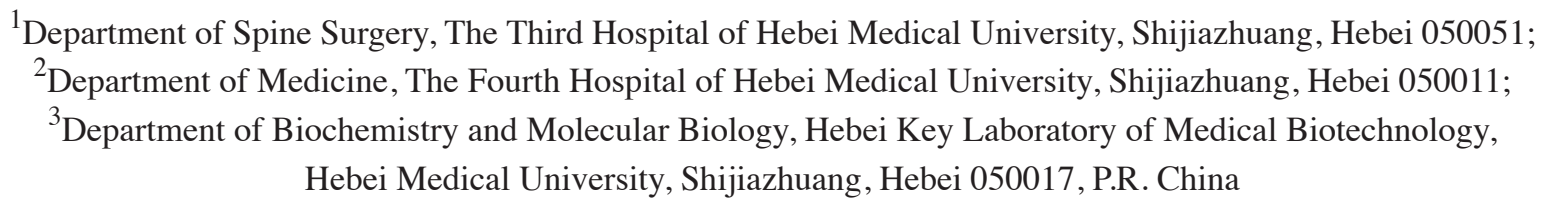

Received February 4, 2014; Accepted September 19, 2014

DOI: $10.3892 / \mathrm{mmr} .2014 .2806$

\begin{abstract}
Catalase is a characteristic enzyme of peroxisomes, of which it is the most abundant protein. This enzyme serves as a typical example of a peroxisomal enzyme and is important in the teaching of biochemistry and molecular biology. Although there is substantial information regarding catalase purification, purifying catalase for the junior-grade undergraduate experimental course face challenges in obtaining materials and increasingly expensive purification equipment. This study presents a simple method for the purification of mouse liver catalase using ethanol-chloroform treatment, sodium sulfate fractionation, dialysis and Sephadex G-200 gel filtration chromatography. Catalase was purified 31.8-fold with an $18.3 \%$ yield. The advantages of this method were its low operating environment requirements, simple procedure and reduced cost. Furthermore, the method was designed to improve students' comprehensive ability and manipulative ability and to introduce a sense of innovation in the fields of biochemistry and molecular biology during their junior year.
\end{abstract}

\section{Introduction}

Catalase (EC 1.11.1.6), the most abundant protein in peroxisomes, is ubiquitously present in mammalian and non-mammalian aerobic cells, which contain a cytochrome system. This enzyme is important in the removal of toxic hydrogen peroxide from the cell. Catalase exists as a dumb-

Correspondence to: Mr. Wenyuan Ding, Department of Spine Surgery, The Third Hospital of Hebei Medical University, 139 Ziqiang Road, Shijiazhuang, Hebei 050051, P.R. China

E-mail: dingwysjz1@163.com

*Contributed equally

Key words: purification, catalase, biochemistry and molecular biology, experimental course education bell-shaped tetramer of four identical subunits, which contains a heme at the catalytic center (1). The molecular weights of the catalases range between 230 and $250 \mathrm{kDa}(2)$. Aydemir and Kuru demonstrated that catalase activity is stable at a broad $\mathrm{pH}$ range between 5.0 and 10.5, and at temperatures between 10 and $30^{\circ} \mathrm{C}$ (3). Catalase is widely used as a typical example of a peroxisomal enzyme during biochemistry and molecular biology teaching due to its specific characteristics, including high efficiency, high specificity and stability.

The crystallization of beef liver catalase was first reported by Sumner and Dounce in 1937 (4). A number of studies, notably those of Price et al on rat liver catalase, of Maimoni Gonçalves et al on human placenta catalase and of Chatterjee and Sanwal on goat lung catalase, have demonstrated various methods of catalase purification in mammals (5-7). Despite developments in molecular cloning and the industrial production of proteins using 'artificial' microorganisms, catalase purification remains an obligatory step due to the cost and complexity of these methods in the majority of circumstances (8).

Although there is now substantial information on catalase purification, the most common limitation in the junior-grade undergraduate experimental course is the expense of the materials and equipment required to perform modern experimental methods. In Chinese medical universities, junior-grade undergraduates are required to undertake two or three school years of study, according to teaching programs, together with their counterparts in the same class. Several basic courses, including biochemistry, molecular biology, physiology and immunology are required during their junior year, from which students are expected to build on a wide knowledge (9). As the junior-grade undergraduates of medical schools are relatively concentrated and are required to learn additional types of courses, the use of new and advanced technologies in undergraduate classes is beyond the budget of the majority of universities and reduce satisfaction in the fundamental courses $(10,11)$. The present study aimed to describe a simple method for purifying catalase from mouse liver that relies solely on ethanol-chloroform treatment, sodium sulfate fractionation, dialysis and Sephadex G-200 gel filtration chromatography. 


\section{Materials and methods}

Animals and reagents. In total, eight 4-month-old Kunming mice of cleaning grade II, weighing between 20 and $25 \mathrm{~g}$, can be used for each pair of students. The mice were supplied from the Experimental Animal Center at Hebei Medical University (Shijiazhuang, China). The absorbance was obtained using a 752 N UV-Vis spectrophotometer (Nanjing Everich Medicare Import and Export Co., Ltd, Nanjing, China) and the relative intensities of the blots were analyzed using a JD801 imaging analysis system (Jiangsu JEDA Science-Technology Development Co., Ltd, Nanjing, China). The rabbit anti-mouse catalase polyclonal antibody and the horseradish peroxidase labeled goat anti-rabbit immunoglobulin $\mathrm{G}$ polyclonal (cat. no. ZB-2301) were purchased from Zhongshan Golden Bridge Biotechnology Co., Ltd. (Beijing, China). The standard catalase was supplied from Beijing Tian Qin Yi He Biotech Co., Ltd. (Beijing, China. The use of animals was reviewed and approved by the Hebei Medical University Animal Ethics Committee (Shijiazhuang, China).

Sodium sulfate fractionation. Sodium sulfate $(0.5 \mathrm{~mol} / \mathrm{l})$ was added to the supernatant by 0.06 volume of supernatant, which produced a marked turbidity and was then left to stand for $1 \mathrm{~h}$ at $4^{\circ} \mathrm{C}$ and centrifuged at $5,100 \times \mathrm{g}$ at $4^{\circ} \mathrm{C}$ for $10 \mathrm{~min}$. The precipitate was dissolved in the minimum quantity of $0.1 \mathrm{~mol} / 1$ sodium phosphate buffer $(\mathrm{pH} 7.8)$ and re-centrifuged at $2,300 \mathrm{x} \mathrm{g}$ for $10 \mathrm{~min}$ to remove the insoluble precipitate.

Dialysis. The supernatant was dialyzed against dialysis buffer ( $0.1 \mathrm{~mol} / 1$ acetate buffer, $0.1 \mathrm{~mol} / 1 \mathrm{NaCl}, 20 \%$ ethanol) at $4^{\circ} \mathrm{C}$ for $12 \mathrm{~h}$, and centrifuged at $5,100 \mathrm{x} \mathrm{g}$ for $10 \mathrm{~min}$. The precipitate was collected by centrifugation $(5,100 \mathrm{x} \mathrm{g}$ for $10 \mathrm{~min}$ ) and dissolved in $0.1 \mathrm{~mol} / 1$ sodium phosphate ( $\mathrm{pH} 7.8$ ). The insoluble material was then removed by centrifugation (2,300 x g for $10 \mathrm{~min})$.

Sephadex G-200 gel filtration chromatography. The supernatant was applied to a Sephadex G-200 column $(1.8 \times 32 \mathrm{~cm}$; Suolaibao Bio-technology Co., Ltd, Shanghai, China), which was previously equilibrated using $0.1 \mathrm{~mol} / 1$ sodium phosphate (pH 7.8). As the liver is rich in catalase, it was possible to use tiny columns of packed materials. The enzyme was eluted with the same buffer at a flow rate of $0.3 \mathrm{ml} / \mathrm{min}$. The peak eluted from the Sephadex G-200 revealed two bands following absorbance analysis at 280 and $406 \mathrm{~nm}$, which were characteristic for the protein and the heme group, respectively. The fractions surrounding the peak, with an $O D 406 / 280$ ratio exceeding 1.08 , were then pooled.

Enzyme assay. Catalase activity was measured using a potassium permanganate titration method (10). For assay of the activity, the enzyme preparation of each purification step was diluted with $0.1 \mathrm{~mol} / \mathrm{l}$ sodium phosphate buffer $(\mathrm{pH} 7.8)$. The diluted enzyme preparation was then added to the buffer containing $40 \mathrm{mmol} / 1 \mathrm{H}_{2} \mathrm{O}_{2}$ and incubated at $25^{\circ} \mathrm{C}$ for $10 \mathrm{~min}$. The reaction was then terminated using $95 \%$ sulfuric acid and the remaining $\mathrm{H}_{2} \mathrm{O}_{2}$ was titrated using $2 \mathrm{mmol} / \mathrm{l}$ potassium permanganate $\left(2 \mathrm{KMnO}_{4}+5 \mathrm{H}_{2} \mathrm{O}_{2}+3 \mathrm{H}_{2} \mathrm{SO}_{4} \rightarrow 2 \mathrm{MnSO}_{4}+\right.$ $\left.\mathrm{K}_{2} \mathrm{SO}_{4}+5 \mathrm{O}_{2} \uparrow+8 \mathrm{H}_{2} \mathrm{O}\right)$. One unit of catalase activity was defined as the quantity of enzyme able to decompose $1 \mu \mathrm{mol}$ $\mathrm{H}_{2} \mathrm{O}_{2} /$ min under standard assay conditions.

The protein concentration was measured using the method detailed by Lowry et al, which used bovine serum albumin (Beinuo Biotech Co., Ltd., Shanghai, China) as the standard protein (12).

Enzyme kinetics. The catalase activity was measured by the increase in hydrogen peroxide concentration ranging between $8 \mathrm{mmol} / \mathrm{l}$ and $40 \mathrm{mmol} / \mathrm{l}$ in $0.1 \mathrm{~mol} / 1$ sodium phosphate $(\mathrm{pH} 7.8)$, according to the method of titration previously described (13). The apparent $\mathrm{Km} \mathrm{H}_{2} \mathrm{O}_{2}$ value was estimated using a Lineweaver-Burk plot.

Determination of the molecular weights of the subunits. The molecular weights of the subunits, assuming a globular structure for the catalase, was determined by SDS-PAGE electrophoresis. The enzyme preparation was separated by SDS-PAGE using a $2.5 \%$ stacking gel and a $12 \%$ running gel. The proteins in the running gel were then made visible by staining with Coomassie Brilliant Blue R-250 (Beinuo Biotech Co., Ltd.). The molecular weight calibration markers were: 94.0, 66.2, 45.0, 35.0, 24.0, 20.0 and 14.4 KDa.

Western blot analysis. The purified enzyme was identified by western blot analysis, in which $4.0 \mu \mathrm{g}$ protein was loaded into each well, separated on SDS-PAGE gels and transferred onto a nitrocellulose membrane. The rabbit anti-mouse catalase antibody was the added to bind to the epitope of the target protein and the primary antibody was recognized by the relative secondary antibody labeled with horseradish peroxidase. The relative intensities of the blots were quantified by densitometry using the JD801 imaging analysis system.

\section{Results}

Catalase purification . The purification profile of the catalase from mouse liver is shown in Table I. The highest specific activity $\left(1.68 \times 10^{5} \mathrm{U} / \mathrm{mg}\right)$ was obtained from the Sephadex G-200 column. Catalase was purified 31.8-fold with an $18.3 \%$ yield. Aydemir and Kulin purified catalase from chicken erythrocyte cytosolic fractions 139.59 -fold with a $1.68 \%$ yield (3). The difference in the purification fold may be due to the present study using only gel filtration chromatography, which increases the ease of performance and reduces the cost of use in the student laboratory.

The $\mathrm{Km}$ value of the enzyme was $32.3 \mathrm{mmol} / \mathrm{l}$, measured using a Lineweaver-Burk plot at $\mathrm{pH} 7.8$ and $25^{\circ} \mathrm{C}$ (Fig. 1). The lower $\mathrm{Km}$ value of $32.3 \mathrm{mmol} / \mathrm{l}$ for mouse liver catalase compared with $93 \mathrm{mmol} / \mathrm{l}$ for bovine liver catalase demonstrated a greater affinity of catalase towards $\mathrm{H}_{2} \mathrm{O}_{2}$ (14).

The molecular weights of the subunits of mouse liver catalase were determined using SDS-PAGE electrophoresis (Fig. 2). The SDS-PAGE revealed one polypeptide band at the expected position at a mass of $58.3 \mathrm{KDa}$. Furuta et al observed subunits with a similar molecular mass of $59.758 \mathrm{KDa}(15)$. The value corresponds to the major monomeric form of the enzyme.

Enzyme identification. This catalase enzyme was confirmed using two techniques. Fig. 3 shows the results of the separation 
Table I. Purification of mouse liver catalase.

\begin{tabular}{|c|c|c|c|c|c|}
\hline Purification step & $\begin{array}{c}\text { Total } \\
\text { activity }(\mathrm{U})\end{array}$ & $\begin{array}{c}\text { Total } \\
\text { protein }(\mathrm{mg})\end{array}$ & $\begin{array}{l}\text { Specific activity } \\
(\mathrm{U} / \mathrm{mg} \text { protein })^{\mathrm{a}}\end{array}$ & $\begin{array}{l}\text { Purification } \\
\text { fold }\end{array}$ & $\begin{array}{l}\text { Yield } \\
(\%)\end{array}$ \\
\hline Homogenate liquid & $1.16 \times 10^{6}$ & 219.7 & $5.29 \times 10^{3}$ & 1.0 & 100.0 \\
\hline Salting-out liquid & $9.70 \times 10^{5}$ & 24.1 & $4.05 \times 10^{4}$ & 7.7 & 83.6 \\
\hline Dialysate & $6.72 \times 10^{5}$ & 4.4 & $1.52 \times 10^{5}$ & 28.7 & 57.9 \\
\hline $\begin{array}{l}\text { Sephadex G-200 gel filtration } \\
\text { chromatography }\end{array}$ & $2.12 \times 10^{5}$ & 1.3 & $1.68 \times 10^{5}$ & 31.8 & 18.3 \\
\hline
\end{tabular}

${ }^{\mathrm{a}}$ One unit of catalase activity is defined as the quantity of enzyme which decomposes $1 \mu \mathrm{mol} \mathrm{H}_{2} \mathrm{O}_{2} /$ min under standard assay conditions.

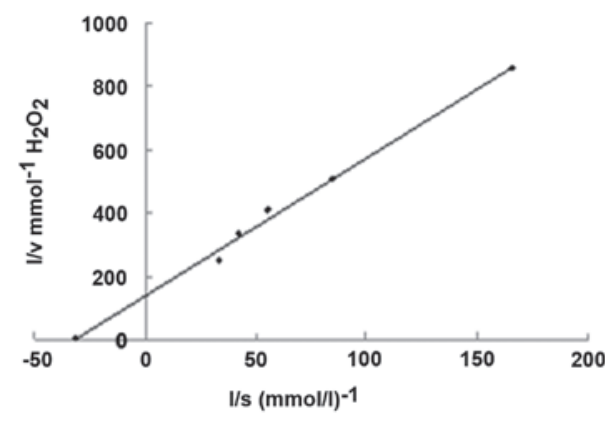

Figure 1. Lineweaver-Burk plot of mouse liver catalase for estimation of the kinetic parameters of the enzyme with a $\mathrm{Km}$ value of 32.3 . The substrate concentration ranged between 8 and $40 \mathrm{mM}$ in sodium phosphate (100 mM, pH 7.8). 1/v, velocity ${ }^{-1} ; 1 / \mathrm{s}$, substrate concentration ${ }^{-1}$.

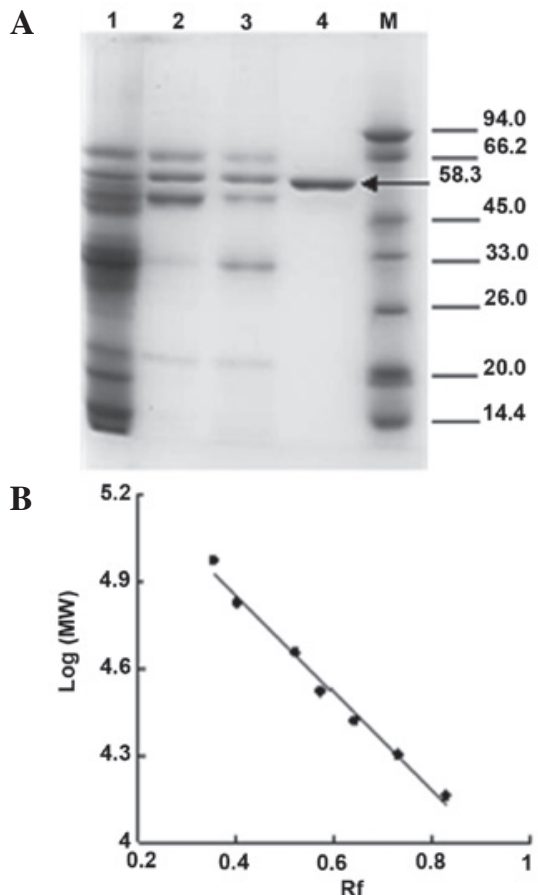

Figure 2. (A) Protein profiles of mouse liver cytosol, which was fractionated by Sephadex G-200 gel filtration chromatography. The proteins were separated by SDS-PAGE using a $2.5 \%$ stacking gel and a $12 \%$ running gel. Following electrophoresis, the proteins were visualized by Coomassie Brilliant Blue R-250 staining. Lane 1, fraction following homogenate; lane 2, fraction following salting-out; lane 3, fraction following dialysis; lane 4, fraction following Sephadex G-200 chromatography; lane M, standard proteins. The molecular weights are indicated in kDa. (B) Molecular weights of purified protein were determined by their Rf. Rf, relative mobility.

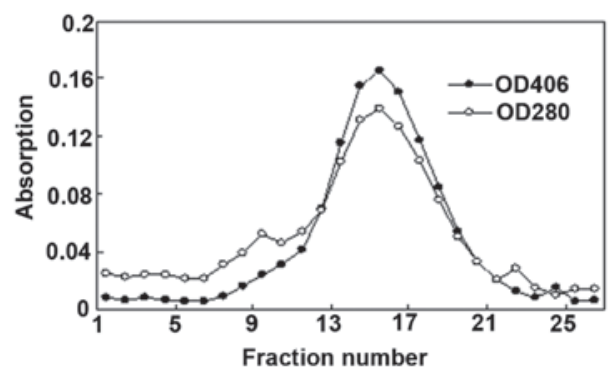

Figure 3. A typical elution profile for the chromatography of catalase from mouse liver crude extract in a Sephadex G-200 column $(1.8 \times 32 \mathrm{~cm})$ equilibrated with $0.1 \mathrm{~mol} / 1$ sodium phosphate $(\mathrm{pH} 7.8)$ at a flow rate of $0.3 \mathrm{ml} / \mathrm{min}$. Absorbance at OD 280 and $406 \mathrm{~nm}$. OD, optical density.

1

2

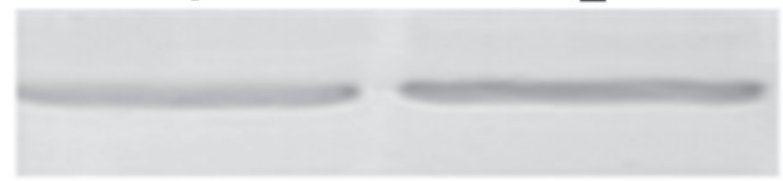

Figure 4. Catalase protein was analyzed using western blot analysis. The protein profiles of the mouse liver cytosol fraction produced one band at the same position as the positive control catalase. Lane 1, purified catalase from mouse liver; lane 2, positive control.

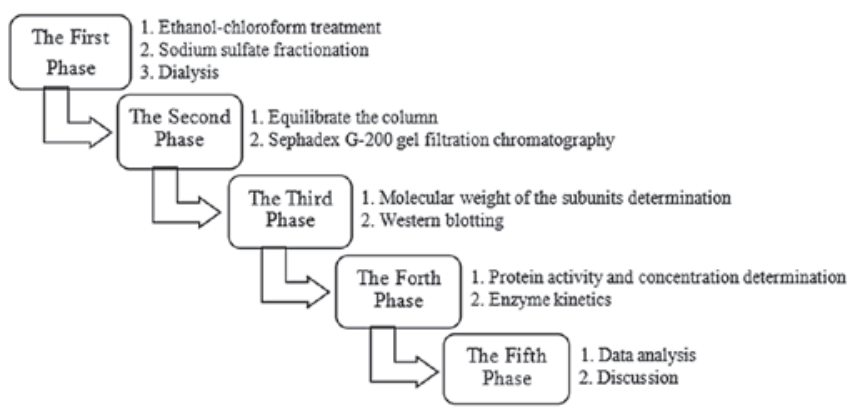

Figure 5. Schedule for the complete catalase purification procedure.

of catalase and other proteins by Sephadex G-200 gel filtration chromatography. The absorption spectrum of the purified enzyme revealed two major peaks at $280 \mathrm{~nm}$ (due to the protein) and at $406 \mathrm{~nm}$ (due to the heme group). The overlapping peak of 280 and $406 \mathrm{~nm}$ was collected and the optical density 
406/280 ratio exceeded 1.08. In addition, western blot analysis was used to identify the enzyme on the basis of the affinity between a certain antigen and its relative antibody. As shown in Fig. 4, one band was observed in the enzyme preparation at the same position as the standard catalase protein control.

\section{Discussion}

The present study demonstrated a straightforward method for purifying catalase from mouse liver that relies solely on ethanol-chloroform treatment, sodium sulfate fractionation, dialysis and Sephadex G-200 gel filtration chromatography. Al-Bar and Omar described a method to purify camel liver catalase by the preparation of crude extract, ammonium sulfate precipitation and chromatography on diethylaminoethyl cellulose-sepharose (16). Although camel liver is rich in catalase, it is difficult to obtain camel liver, which limits its use for junior-grade undergraduates. Yang and DePierre presented a method of purification from mouse liver catalase by immobilized metal ion affinity chromatography (17), however, this was expensive and complex to perform due to the requirement of prior treatment to materials. By comparison, the purification procedure described in the present study did not require specific equipment and was performed using the material and apparatus present in the majority of student laboratories, making it adaptable to the junior-grade undergraduate experimental course.

It is possible that the method described in the present study, can be performed, with data analyzed and discussed, in 2-3 days as the liver is rich in catalase, the method is sensitive and few materials are used. In addition, due to the high stability of catalase, the flexibility of the procedure enables it to be finished continuously or discontinuously in stages. In the majority of China's medical schools, the experimental course is not a separate course, but is included in the fundamental courses taught during theoretical knowledge teaching (18). The majority of junior-grade undergraduates only have a 4-hour biochemistry and molecular biology experiment course every week and are unable to complete a large purification experiment in one occasion; therefore, the method presented in the present study many be more popular as students are able to complete the purification procedure in phases according to their experiment course arrangements. An example of a schedule for the overall operation procedure is shown in Fig. 5.

In addition, the method introduces several fundamental laboratory theories to students in terms of biochemistry and molecular biology. These theories include that of dialysis, the process of separating molecules in solution by differences in their rate of diffusion through a semipermeable membrane and chromatography, the technique of separating components of a mixture according to the different affinities for a fixed or stationary phase and their differential solubility in a moving or mobile phase. Students are able to acquire two separation techniques through the entire procedure. In addition to the theoretical knowledge inherent to the purification procedure, the purified enzyme can be used to learn certain basic enzyme characterization techniques, including western blotting, determination of protein activity and concentration and protein molecular weight determination.

In conclusion, the present study demonstrated the purification of mouse liver catalase using basic equipment, common to the majority of junior-grade undergraduate laboratories. Throughout this purification process, students are able to gain experience of laboratory techniques, acquire valuable data analyzing skills and understand research ideas, which are highly relevant to biochemistry and molecular biology. In addition, the procedure described has the potential to improve the comprehensive and manipulative ability of students, and develop their sense of innovation in their junior years.

\section{Acknowledgements}

This study was supported by the Higher Education Reform Project of Hebei Province of China. The authors would like to thank Dr Lingling Jiang of the Institute of Basic Medicine for their critical evaluation.

\section{References}

1. Kirkman HN and Gaetani GF: Mammalian catalase: a venerable enzyme with new mysteries. Trends Biochem Sci 32: 44-50, 2006.

2. Baird MB, Massie HR and Birnbaum LS: Presence of a high-molecular-weight form of catalase in enzyme purified from mouse liver. Biochem J 163: 449-453, 1977.

3. Aydemir T and Kuru K: Purification and partial characterization of catalase from chicken erythrocytes and the effect of various inhibitors on enzyme activity. Turk J Chem 27: 85-97, 2003.

4. Sumner JB and Dounce AL: Crystalline catalase. Science 85: 366-367, 1937

5. Price VE, Sterling WR, Tarantola VA, Hartley RW Jr and Rechcigl M: The kinetics of catalase synthesis and destruction in vivo. J Biol Chem 237: 3468-3475, 1962.

6. Maimoni Gonçalves V, Cezar de Cerqueira, Leite L, Raw I and Cabrera-Crespo J: Purification of catalase from human placenta. Biotechnol Appl Biochem 29: 73-77, 1999.

7. Chatterjee U and Sanwal GG: Purification and characterization of catalase from goat (Capra capra) lung. Mol Cell Biol 126: 125-133, 1993.

8. Alenkin D, Yermekbayeva L, Mujib S, Vesterberg A, Newman E, Yamazaki K, Cossar D and Dhe-Paganon S: A centrifugation-free high-throughput protein purification system using in-line microfluidization. Protein Expr Purif 79: 204-209, 2011.

9. Lam TP, Wan XH and Ip MS: Current perspectives on medical education in China. Med Educ 40: 940-949, 2006.

10. Wang $\mathrm{HF}$ and Zhan $\mathrm{HJ}$ : The research progress in determination of catalase activity. Science and Technology Innovation Herald 19: 7-8, 2009.

11. Xiao WW, Ma WL and Zhang XM: Present situation of biochemical experiment teaching and its reform strategies. Xi Bei Yi Xue Jiao Yu 15: 270-271, 2007 (In Chinese).

12. Lowry OH, Rosebrough NJ, Farr AL and Randall RJ: Protein measurement with the Folin phenol reagent. J Biol Chem 193: 265-275, 1951.

13. M Dixon: The graphical determination of $\mathrm{Km}$ and $\mathrm{Ki}$. Biochem J 129: 197-202, 1972.

14. Switala J and Loewen PC: Diversity of properties among catalases. Arch Biochem Biophys 401: 145-154, 2002.

15. Furuta S, Hayashi H, Hijikata M, Miyazawa S, Osumi T and Hashimoto T: Complete nucleotide sequence of cDNA and deduced amino acid sequence of rat liver catalase. Proc Natl Acad Sci USA 83: 313-317, 1986.

16. Al-Bar and Omar AM: Characterization of partially purified catalase from camel (Camelus dromedarius) liver. Afr J Biotechnol 11: 9633-9640, 2012.

17. Yang Q and DePierre JW: Rapid one-step isolation of mouse liver catalase by immobilized metal ion affinity chromatography. Protein Expr Purif 12: 277-283, 1998.

18. Schwarz MR, Wojtczak A and Zhou T: Medical education in China's leading medical schools. Med Teach 26: 215-222, 2004. 